Section, in conjunction with the Public Library Association, offered an all day conferencewithin-a-conference: "Community College and Public Libraries: The Impetus toward Cooperation!" The Rare Books and Manuscripts Section sponsored "Rarities and Ephemera at the Chicago Historical Society Library: an Illustrated Lecture."

The Slavic and East European Section offered a three-part program, which included "Reflec- tions on the History and Prospects of Slavic Bibliography in the United States," "The Automation of Cyrillic Slavic Cataloging," and "Current Developments in Romanization of Cyrillic Scripts."

Trips sponsored by ACRL units included the Law and Political Science Section's tour of Chicago City Hall, the Art Section's boat ride on Lake Michigan, and CJCLS's tour of four libraries of the City Colleges of Chicago.

\title{
Association of College and Research Libraries Annual Report of the President 1977-78
}

This has been an active and productive year for ACRL. We have addressed or are in the process of addressing several major issues that are of considerable importance to our association and its members.

Plans and arrangements are moving along most efficiently for our first national conference. A major staff appointment was made. Arrangements were worked out for an annual award for achievement by an academic librarian. Other ACRL programs produced results worthy of recognition. In addition, ACRL, during 1977-78, addressed several ALA-wide issues that have significant impact on our association. Finally, we gave attention to concerns that we share with other organizations.

The major critical issues addressed by the association this year included the following. First, we made a beginning evaluation of our association's objectives and the organizational structure needed to carry them out effectively, based upon the report of the special ACRL Ad Hoc Subcommittee on Goals, Priorities, and Structures. Second, we established a mechanism to assist our members in addressing the complex and difficult issues raised by the new copyright legislation. Third, we gave substantive review to the draft university libraries standards prepared by a joint ARL/ACRL committee. Finally, we addressed the particularly complex and critical issues related to ownership of public documents, as raised by the $\mathrm{B}$. C. West case.

The Subcommittee on Goals, Priorities, and Structures was established in the fall of 1973 by ACRL President Norman Tanis with the following charge: (1) to describe the changing environment of research and postsecondary education; (2) to identify the issues and problems relating to information and library service in this environment; (3) to determine the role for an association such as ACRL in responding to these issues and problems; (4) to disregard all financial aspects or the constitutionality of its suggestions.

The committee, chaired by LeMoyne W. Anderson, submitted its recommendations, which included proposals for significant changes in ACRL's activities and structure, in the fall of 1977. The subcommittee's report was referred, by the ACRL board, to our Planning Committee. This committee is reviewing the report and will make recommendations regarding its implementation to the ACRL board.

The Subcommittee on Goals, Priorities, and Structures was discharged with an expression of the board's great appreciation. Certainly, the work of this committee will facilitate ACRL's ability to address the major issues that lie before us. Its recommendations may also contribute to some significant changes in the organization and structure of our association.

Prior to the ALA Midwinter Meeting, ACRL was requested by ALA to assume responsibility for developing guidelines on photocopying of coyrighted materials that could be utilized by academic libraries.

After discussing this issue with William D. North, ALA legal counsel, who met with us at Midwinter, the ACRL board concluded that ACRL should not, at this point, attempt to develop and publicize guidelines in this area. On the other hand, the board recognized the need for identifying, in detail, the problems that academic libraries and librarians are encountering as a result of the new copyright legislation.

Consequently, it was decided that an ad hoc committee on copyright questions should be appointed within ACRL, with the task of identifying questions and issues in this area that are of concern to ACRL members which require legal interpretation or attention. These questions would then be forwarded to North for his review, recommendations, and appropriate legal action on the part of ALA. This committee has been appointed and has set about its task. 
At the same time, CdRL News has given particular attention to copyright issues, with the publication of two important articles during $1977-78$ and plans for further publication in the near future.

In the spring of 1978, the Joint ARL/ACRL Committee on University Library Standards produced a proposed standards document, which was submitted to the Boards of Directors of both organizations. This document was published in the April issue of C $d R L$ News. It is being reviewed by the ACRL Standards Committee and the ACRL University Libraries Section Steering Committee, each of whom sponsored a discussion session on the proposed standards, open to all ACRL members, at the ALA Annual Conference.

These standards will come before the ACRL board for final action at next Midwinter. As I find myself in the peculiar position of being the chair of this joint committee as well as president of ACRL, it is difficult for me to comment, in any objective way, about the committee's work. I will express my strong hope, however, that either ACRL and ARL adopt these standards or give up, at least for the time being, our long-standing and perpetually unsuccessful efforts in this area.

The final major issue that ACRL addressed during the past year was the question of ownership of state documents, as this matter seemed to stand following the results of $B$. C. West v. North Carolina. William North reviewed this case and its implications at some length with the ACRL board during Midwinter.

Recognizing that, as a result of this case, there are serious questions regarding legal ownership of prerevolutionary U.S. publications, the ACRL board formally recommended that the American Library Association design an appropriate form of lawsuit, perhaps as a suit to quiet title to state papers in private collections, and institute it in a suitable local or state environment, with the possible further intention of an appeal to the U.S. Supreme Court on federal issues, which would thereby be isolated.

The board recommended that ALA establish an advisory committee to legal counsel in consultation with ACRL for this purpose. ALA President Eric Moon appointed such a committee, including strong ACRL representation. They held their first meeting during the 1978 Annual Conference.

During 1977-78, most of the final plans and arrangements were concluded for ACRL's first national conference, which will be held November 8-11 in Boston, Massachusetts. The Conference Planning Committee, chaired by George $\mathbf{R}$. Parks, has done a truly outstanding job. This conference, with its emphasis on program, should be a truly signal achievement for ACRL and its members. Indeed, it does not seem an exaggeration to suggest that the future of ACRL will be significantly altered as a result of this conference.

It gives me particular pleasure to note that, during 1977-78, Louis A. Sasso was appointed editor of Choice. I am convinced that, with his background, experience, and ability, Sasso will make an outstanding contribution to ACRL in this capacity. I would like to take this opportunity to commend the search committee, which was chaired by Beverly P. Lynch, for the outstanding success of its efforts.

During this past year, successful arrangements were worked out with the Baker \& Taylor Company for the establishment of an annual ACRL Baker \& Taylor Award to be given annually to an individual member of the library profession who has "made an outstanding national or international contribution to academic librarianship and academic development." This award, which will carry an annual stipend of $\$ 2,000$, is modeled on the AASL/Baker \& Taylor Award. Formal announcement of the award was made at the reception following the ACRL program meeting at the 1978 Annual Conference. The first award will be given at the ACRL National Conference in Boston

I am particularly pleased with this development. It characterizes, I believe, ACRL's longstanding emphasis on the "librarian" in "librarianship." I also wish to express my personal appreciation, as well as that of ACRL, to the Baker \& Taylor Company for making this award possible. Certainly, their interest in sponsoring this award demonstrates their own commitment to furthering academic librarianship.

Like most other professional and highereducation organizations, ACRL has recognized the critical importance of continuing education for its members. In order to address this issue most effectively, a Continuing Education Committee was established and appointed last year by ACRL President Connie Dunlap. This committee, under the chairmanship of Richard Werking, has addressed itself vigorously and imaginatively to its task.

It is giving particular attention to gathering membership opinion regarding continuing education needs for academic librarians as well as publicizing continuing education opportunities to ACRL members. C $\& R L$ News has provided excellent support to the committee's efforts in both of these areas. In addition, the committee provided valuable advice to our association with regard to ALA continuing education plans, discussed below.

It is literally impossible, within the compass of a report such as this, to recognize all the significant actions that took place within ACRL last year. Let me only say that most of our sections, committees, discussion groups, and chapters were active and productive. Particular note should be made of the continuing ACRL activity in such areas as academic status, standards, and bibliographic instruction.

Mention should also be made of the following 
developments. The Asian and African Section has produced a directory of Asian-African librarian specialists. The Supplemental Funds Committee has been reorganized. Funding is being provided from the ACRL budget to support the travel of ACRL Executive Committee members to visit ACRL chapters-an effort to strengthen this extremely important area of ACRL activity.

ACRL is, of course, a division of the American Library Association. Consequently, ACRL and its members participate heavily in ALA activities and programs. During the past year, several areas of ALA activity were particularly important for ACRL. These included, in addition to the copyright and $B$. C. West matters that have already been discussed, issues related to the ongoing evaluation by ALA of its structure, continuing education matters, that ALA draft policy on prejudice, stereotyping, and discrimination, and collective bargaining.

A matter of obvious and potentially far-ranging concern to ACRL is the work of ALA's Ad Hoc Committee on Future ALA Structure. The board discussed this document at Midwinter. At that time, the three ACRL directors-at-large, Billy Wilkinson, Jane Flener, and William Studer, were asked to prepare specific comments for discussion at the Annual Conference. This is obviously a matter on which ACRL must make its voice heard within ALA.

At Midwinter, the ACRL board also reviewed a memorandum from ALA Executive Director Robert Wedgeworth regarding ALA and continuing education. Richard Werking, chair of the ACRL Continuing Education Committee, expressed to the ACRL board that committee's concerns that: (1) the association not launch continuing education programs before studies are carried out to determine more precisely what the needs are in this area; and (2) that ALA give specific attention to the assistance it can provide divisions in developing continuing education programs that are relevant to the particular interests of their membership. ACRL is continuing to work with the American Library Association on this matter.

ACRL has also expressed concerns to the American Library Association in two other areas. After reviewing the draft resolution on prejudice, stereotyping, and discrimination, which has been developed as a possible policy statement by the association, the ACRL board requested that a resolution be achieved to a possible conflict that it sees between the Library Bill of Rights and the draft resolution before ACRL undertakes any new steps to supplement its ongoing programs relating to these issues. The ACRL board also recommended certain revisions in the "Collective Bargaining Statement of Policy" before it is adopted by the American Library Association.

At the Midwinter Meeting, the ACRL board, at the request of the ACRL Committee on Legis- lation and its chair, Susan Brynteson, passed a motion in support of the position of the American Association of Univergity Professors that tenured faculty members not be considered exempt from protection under federal legislation extending the mandatory retirement age.

In a separate action, following a report from Frank Schick regarding collection and publication of library data by the National Center for Education Statistics, the board formally expressed its concern to NCES that this data continue to be collected and published on an annual rather than the contemplated biennial basis. It should also be noted that the work discussed above with regard to university libraries standards is a joint effort of ACRL with the Association of Research Libraries.

No review of ACRL's activity during this interesting, exciting, and productive year would be complete without a recognition of the particular contributions of our headquarters staff. Julie A. C. Virgo, in her first full year as executive secretary, has done a truly outstanding job. The other members of the staff-Lynn C. Dennison, Virginia Wilcox-Wachsmuth, Robert Meinz, and Hal Espo-not only have been extremely efficient and productive but are invariably helpfu] and goodhumored, frequently beyond the call of duty and even under the most difficult circumstances. It has been a pleasure to work with them.

Lynn Dennison, who resigned in February after more than five years of service with our association, left an outstanding record and many, many friends behind. She will be missed. Hal Espo, who filled the program officer position, has been on the job since May 1. Julie Virgo has not only had to learn a great deal under pressure but cope with a president who, because of a recent change in his own position, has had to rely very heavily upon her during his year in office. Certainly, ACRL and its members should be very pleased that we have another outstanding person as executive secretary.

Finally, of course, I must express my great appreciation for the help and support that I have received from our past president, Connie Dunlap, President-Elect Evan Farber, the members of the ACRL board, and the ACRL committees, sections, chapters, and their chairpersons. They are a hardworking, devoted, and extremely constructive group.

Finally, my thanks and appreciation to the ACRL membership. We are, without question, a vital, dynamic organization. Nothing makes this clearer than the work that has been invested in planning and developing the forthcoming national conference. It has been a great honor and a distinct pleasure for me to have the opportunity to serve this year as president.

Eldred R. Smith President, ACRL 


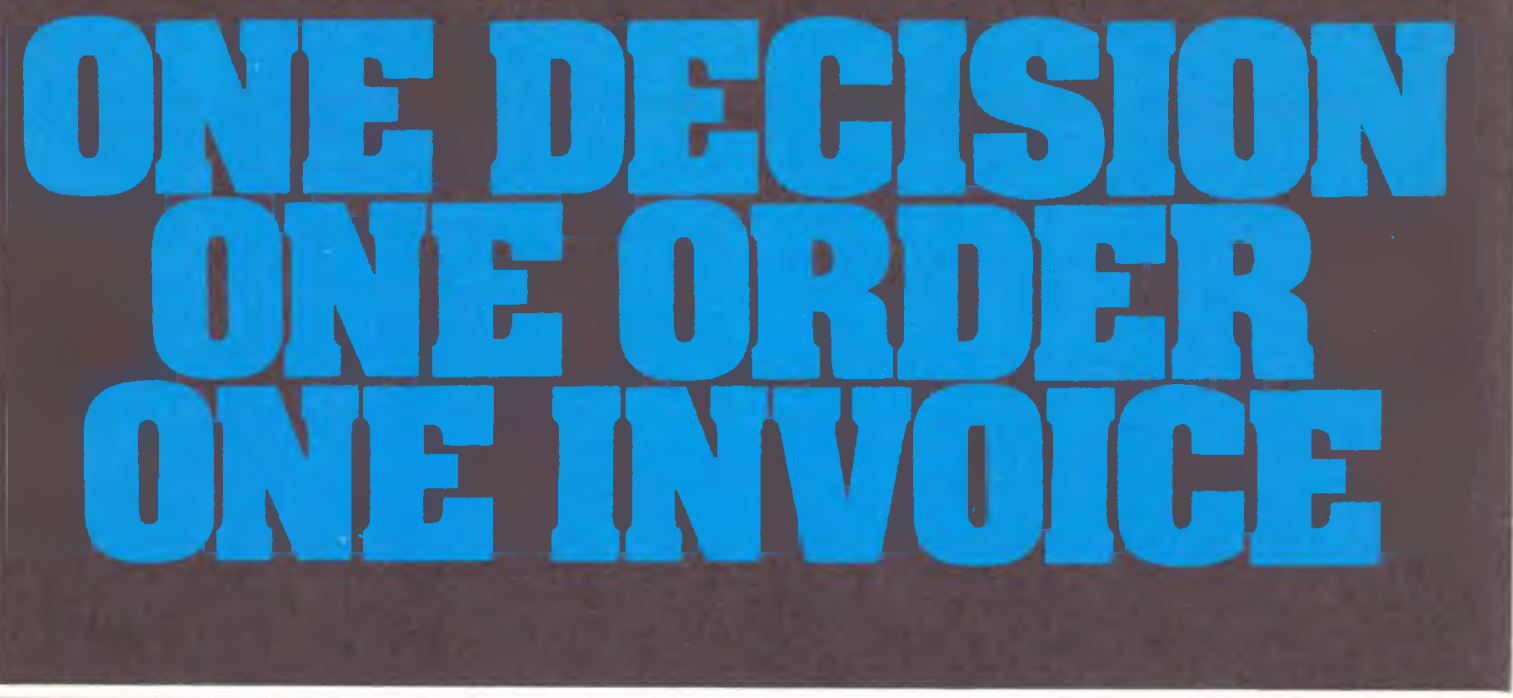

\section{for your year's subscription of periodicals on microform}

To keep paperwork down and the quality and integrity of your periodicals collection up, University Microfilms International devised the Serials on Microform Subscription Service.

Under the Subscription Service, you ... .

- place one microform order for all current periodical subscriptions-at any time throughout the year

- receive one invoice for the entire order soon after the order is placed for greater budget control.

The periodicals ordered will automatically be shipped to your library as soon as they are available. Because you're going through one source for all your microform subscriptions, your ordering and billing paperwork is reduced.

In addition, quarterly status reports keep you up to date on your order, and the annual renewal notice serves a double function as a convenient reorder form.

Another important benefit of this service is that it eliminates the three to six months of reference time lost to your researchers while periodicals are at the bindery. Paper issues can remain on your shelves and in use until replaced by the microform edition.

Because you're ordering microform, you get all these benefits, too-durability, cost savings, unequalled file integrity and maximum use of available space.

Find out more about the Serials Subscription Service by returning this coupon.

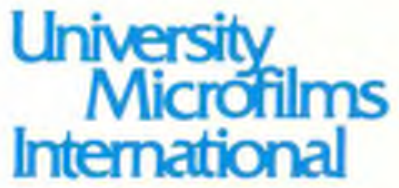

300 North Zeeb Road/Ann Arbor, MI 48106 800-521-3042
YES, I would like more information on the Serials Subscription Service.

Please send me the Subscription Catalog.
MAIL TO: Serials Publishing University Microfilms International 300 North Zeeb Road Ann Arbor, Michigan 48106

Name

Title

Library 